\title{
The river basins of Pirapó, Paranapanema 3 and Paranapanema 4: socioeconomic and environmental aspects
}

\author{
A. M. G. Godoy ${ }^{a, b *}$ and M. L. L. Sousa ${ }^{b}$ \\ a Department of Economics - DCO, Universidade Estadual de Maringá - UEM, \\ Av. Colombo, 5790, CEP 87020-900, Maringá, PR, Brazil \\ 'Post-graduate Program in Economics - PCE, Universidade Estadual de Maringá - UEM, \\ Av. Colombo, 5790, CEP 87020-900, Maringá, PR, Brazil \\ *e-mail: amggodoy@uem.br
}

Received: January 17, 2015 - Accepted: May 20, 2015 - Distributed: November 30, 2015

(With 1 figure)

\begin{abstract}
Scarcity of water in the world, virtually, has two sources: the quality and the quantity made available for populations. In the area covered by this study, the selected municipalities from the river basins 3 e 4 of the Paranapanema River and from the basin of the Pirapó River, availability is always greater than the demand and the environmental problems are more often linked to the quality than to the quantity of water. To check the socioeconomic aspects and the daily practices involving water resources and environmental problems we selected a representative sample of families from 10 studied municipalities. The main conclusions point to the existence of key municipalities, regarded as foci of pollution, i. e., the municipalities do not contribute in equal measure to the pollution of rivers from their regions and some stand out in economic activities and inherited cultural practices. However, respondents did not always relate the environmental impacts with their routine and productive activities. Thus, although the new legal environment imposes new practices, there are still cultural heritages, which require more incisive and continuous public interventions.
\end{abstract}

Keywords: river basins, Paranapanema 3, Paranapanema 4, Pirapó, environment.

\section{As bacias hidrográficas do Pirapó, Paranapanema 3 e Paranapanema 4: aspectos socioeconômicos e ambientais}

\section{Resumo}

A escassez das águas, no mundo inteiro, praticamente, tem duas fontes: a qualidade e a quantidade disponibilizada para as populações. Na área de abrangência do presente estudo, nos municípios selecionados das bacias hidrográficas do Paranapanema 3 e 4 e o Pirapó, a disponibilidade é sempre maior que a demanda e os problemas ambientais estão ligados mais à qualidade do que a quantidade de águas. Para verificação dos aspectos socioeconômicos e das práticas cotidianas que envolvem os recursos hídricos e os problemas ambientais selecionou-se uma amostra significativa de famílias dos 10 municípios estudados. Como algumas conclusões tem-se que existem municípios-chaves focos de poluição, ou seja, os municípios não contribuem de maneira igual para a poluição dos rios de suas regiões e alguns se destacam nas atividades econômicas e incorretas práticas culturais herdadas. Contudo, os impactos ambientais nem sempre são relacionados, pelos entrevistados, com as suas atividades rotineiras e produtivas. Com isso, por um lado, verifica-se que o novo ambiente legal impõe novas práticas, contudo, por outro lado, ainda persistem as heranças culturais herdadas que, o que exige intervenções públicas mais contundentes e contínuas.

Palavras-chave: bacias hidrográficas, Paranapanema 3, Paranapanema 4, Pirapó, meio ambiente.

\section{Introduction}

For some time in Brazil and in the world, water, virtually, has two sources of scarcity: the pollution that changes the water quality and restrictions on the amount available due to growing demand, changes in the hydrological cycle and inefficient use. In general, it is understood that the scarcity of water due to pollution is a more frequent problem in the South and Southeast regions of Brazil, which concentrates the major industrial and agricultural uses, higher population contingent and treatments whose efficiency is uneven.

Therefore, this article is based on the fact that existing practices in the study area have an impact on changes in the quality of water supplied to the different municipalities. The environment that contextualizes this article is characterized 
by changes and transformations, because on the one hand, there is the cultural heritage of interaction between people and their activities and the physical environment, which is difficult to be modified and, on the other hand, due of inheritance, the differentiated values that the physical environment has for different populations and needs to be modified, because the legal environment imposes new dynamics both in urban as in rural sector.

In this context, this study aims to present socioeconomic aspects of the municipalities from the Basins 3 and 4 of Paranapanema River and the Basin of Pirapó River, which suffered severe process of forest clearing due to the introduction of raw materials and heavy farming implements typical of the green revolution, and the presence of large cattle in highly sensitive environments like Caiuá Sandstone, which are in a legal environment that has a series of rules imposing new relationships with nature.

To verify the practical and assuming that the socioeconomic development of each watershed is different, we conducted a field research with a statistically representative sample, to identify both the socioeconomic features of the population in urban and rural households as the understanding of the respondents about the environmental problems surrounding them.

This study is organized into five sections. The first relates to this presentation and the second is related to the context of analysis. The next section presents the methodology and the fourth section shows some results of the field research. Finally, we present some conclusions.

\section{The Background of the Analysis}

Until the mid 1980s, the management of water resources was fragmented, sectoral and focused on corrective actions. Agricultural and urban practices were not very concerned about environmental impacts and deterioration of rivers. However, changes in the legal environment, with the National Policy for the Environment (BRASIL, 1981), the Constitution of 1988 (BRASIL, 1988) and the National Water Resources Policy (BRASIL, 1997), have imposed new relationships with the physical environment.

As one of the policies that guide the minimization of impacts on water resources, the Law 9433 of January 8, 1997 (BRASIL, 1997) known as the Water Law either the National Water Resources Policy, which aims to (i) ensure to the current and future generations the availability of water, according to quality standards suitable; (ii) the rational and integrated use of water resources, including waterborne and waterway transportation, with a view to sustainable development; and (iii) the prevention and defense against critical hydrological events occurring naturally or resulting from inappropriate use of natural resources. With this Act, the river basin became the management unit, which became more integrated and centrally focused that water is a limited natural resource (art. 1, II), has multiple uses such as public water supply, industrial, agricultural irrigation, electric power generation, recreation and preservation of aquatic life (Art. 1, IV). Furthermore, private waters were converted into the public domain (Art. 1, I), i.e., may be used only by granting the right to use.

In the same Act, the river basins become the focus of policies outlined by the River Basin Committees (BRASIL, 2000). In the state of Paraná, the State Law 12,726 of November 26, 1999 (PARANÁ, 1999) follows the same principles of the Federal Law.

In spite of these undeniable normative progresses, in most Brazilian states, the directions of water policies are under the jurisdiction of various state departments which means in practice that the integrated coordination is still incipient or non-existent and / or conflictual. Furthermore, there is a cultural heritage that extends over time on cultivation and cattle-raising techniques and use of raw materials, which are difficult to be broken. As a result, problems and environmental impacts extend and intensify, with degradation and intensive use of land and water, even due to the high degree of dependence of the ways of producing, which changes the access to water resources in quantity and quality as well as the hydrologic cycle in space and time.

One of the aspects to be taken into consideration, as the focus of this article is that environmental degradation is caused by inadequate uses and practices that drive both greater exploitation of water resources as well as their pollution which in turn generate greater social and environmental imbalances.

Specifically, in the study area, the agricultural modernization in the 1970s and 1980s, which aimed to intensive and extensive grain production for export and the formation of large agro-industrial complexes, the result was the rapid removal of forests, siltation of rivers and the deterioration of water sources particularly those that supply the urban areas as well as the emergence of gully erosion that destroyed regions and required substantial public investment. In the urban sector, inadequate or non-existent treatment of industrial and domestic effluents contributes to the decrease in the quality of water resources.

In this context, the study focuses on Basins 3 and 4 of Paranapanema River and on the Pirapó River, their urban and rural characterization and the identification of environmental problems perceived by the studied families, presented in the following section.

\subsection{Features of the studied river basins}

Located in the north of the state of Paraná, the Basin of Pirapó River and the Basins 3 and 4 of Paranapanema River (from a total of 16 basins in the state of Paraná, according to Resolution 024/2006, from SEMA / PR), covers an area of $11,691.27 \mathrm{~km}^{2}$ (from a total of $196,490.01 \mathrm{~km}^{2}$ ) and encompass 56 municipalities (out of a total of 399 municipalities in the state, as shown in Map 1) (PARANÁ, 2006).

The River Basin Paranapanema 3 reaches a total of 15 municipalities in an area of $5,400.16 \mathrm{~km}^{2}$, which are equivalent to $27 \%$ of the studied area. It is formed by the drainage area of 12 tributaries that flow into the Paranapanema River between the mouth of the Tibagi 


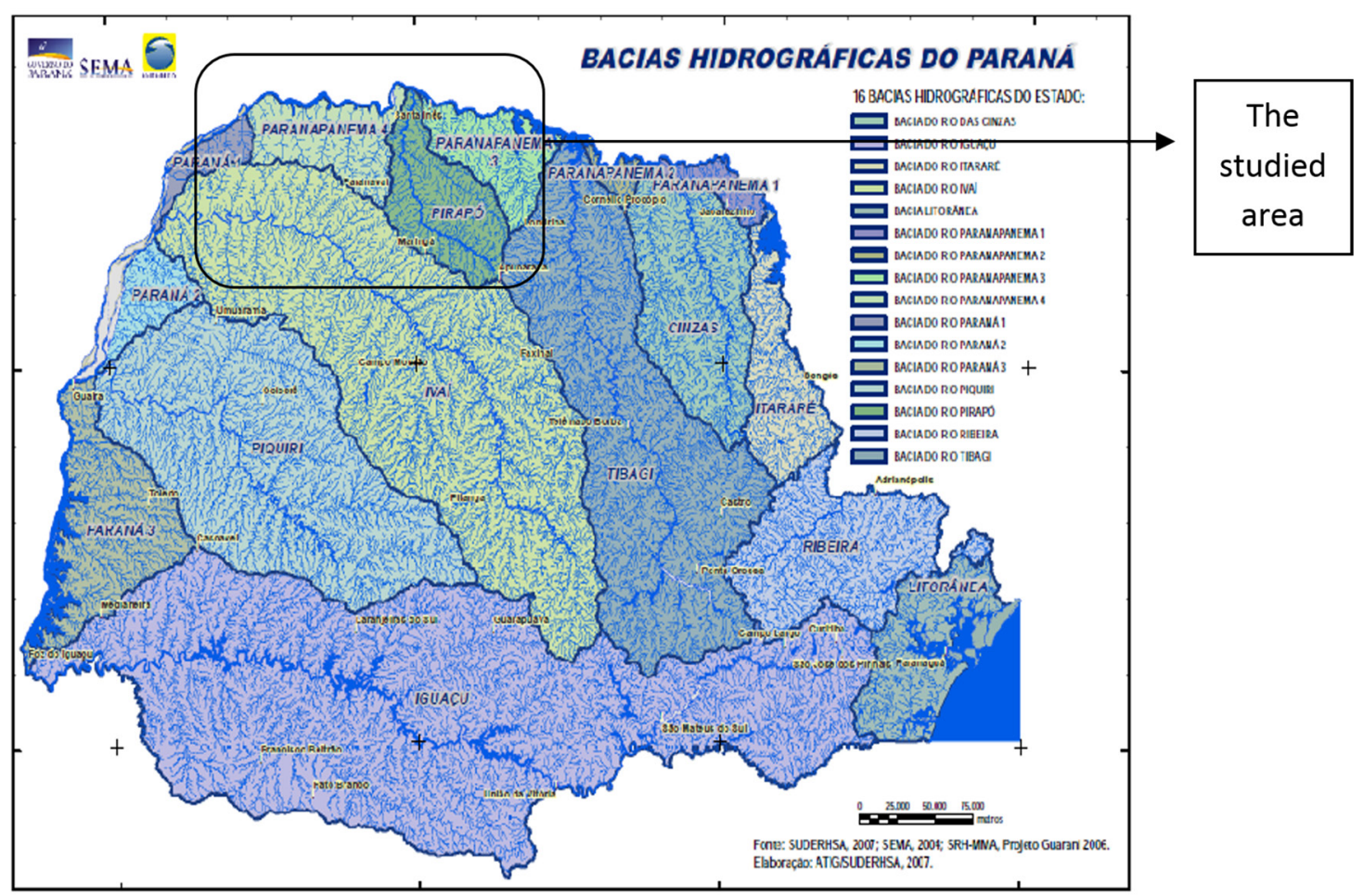

Map 1. The River Basins of the state of Paraná and the studied area. Source: Paraná (2007).

River, near the lake of the Hydropower Plant Capivara and the mouth of the Pirapó River (PARANÁ, 2010, p. 92).

The River Basin Paranapanema 4 reaches a total of 15 municipalities in an area of $6,290.77 \mathrm{~km}^{2}$ or $31 \%$ from the studied area) is located to the west of the river Pirapó, with 15 tributaries of Paranapanema River until the mouth of the Ribeirão do Tigre (PARANÁ, 2010, p. 98).

Most of these basins ( 3 and 4 ) are located in Sandstone Caiuá that as Paraná (PARANÁ, 2012a), about $80 \%$ is for public supply, from region covered by the Caiuá aquifer, which is done through groundwater (See the Map 1).

The Pirapó River Basin (26 municipalities and area of $8,502.30 \mathrm{~km}^{2}$ or $42 \%$ of total), has Pirapó river as the major component. The source of the river is in the municipality of Apucarana, about 1,000 meters above sea level, flows northward and covers an extension of $168 \mathrm{~km}$ to its mouth at Paranapanema river, approximately 300 meters above sea level in the municipality of Jardim Olinda. Approximately 60 direct tributaries comprise the basin. The Bandeirantes do Norte River is its largest tributary, has its source in the municipality of Arapongas and has an extension of $106 \mathrm{~km}$ (PARANÁ, 2010, p. 86). This river basin is located in the Serra Geral System (PARANÁ, 2012a).

The water catchment in these river basins is mainly used for human consumption in the case of Pirapó; for industrial use in Paranapanema e and Pirapó and, finally, for irrigation in Paranapanema 3 (PARANÁ, 2012a). Moreover, the coverage of the treatment of sewage is low.

According Godoy and Sousa (2012), the total population of the three basins is 1,362,109 inhabitants. From these,
$87,134(6 \%)$ live in the rural sector and 1,274,975 (94\%) in the urban sector. The Pirapó river basin concentrates most of the population with 956,806 inhabitants $(70.2 \%$ of the total population of the three basins), and 909,776 (95\% from the Pirapó river basin) are in the urban sector while 47,030 ( $5 \%$ of the basin) are in rural sector.

Urban households are 447,756, of which 320,328 (71.5\% of the total) are in the Pirapó, 62,534 (14.0\%) are in the Paranapanema 3 and 64,894 (14.5\%) are located in Paranapanema 4.

The existing farm units in the three river basins amount to 28,147 in a total area of $1,659,796$ hectares. From these, 15,176 farm units (53.9\% of the total, with an area of $722,545 \mathrm{ha}$ ) are located in the Pirapó basin; 7,256 units $(25.8 \%$ with an area of 556,915 ha) are in the Paranapanema 4 and in the Paranapanema 3 basin there are 5,715 properties $(20.3 \%$, corresponding to $380336 \mathrm{ha}$ ). Regarding the individual size of the farms, 7,745 are micro farms and 14,991 are small, i.e., those categories are 22,736 farm units ( $80.8 \%$ of total). There are 2,800 properties ( $10.2 \%$ of total) classified as large, highly concentrated in the Pirapó river basin.

The River Basin Paranapanema 3 is characterized by having a high rate of deforestation since the 1980 s. Currently remains about $5 \%$ of remaining coverage, of which $4 \%$ is protected by the Conservation Units of Integral Protection. Temporary crops are featured at 2,750 properties, which occupy an area of 229,229 ha and permanent crops are in 792 properties and occupy an area of 61,075 ha (Godoy and Sousa, 2012). The region has a predominant use of 
intensive agriculture in $90 \%$ of the territory. Based on the occupied area, the main activity is the cultivation of cane sugar (higher production), which stand out municipalities of Porecatu (area of 9,455 ha, which produced 772823 tons), followed by Santo Inácio $(9,750$ ha and 729,970 tons produced) and Centenário do Sul (8,533 ha and 707,300 tons). Soybeans is the second largest activity according to the occupied area, especially in the municipalities of Cambé (32,000 ha and 102,400 tons), followed by Primeiro de Maio (21,887 ha and 68,287 tons) and Alvorada do Sul (19,650 ha and 61,308 tons). The Paranapanema 3 river basin has 4,731 farm units and 340,961 ha are managed by the owners. Lessees cultivate an area of 24.312ha and settlers are responsible for 9.380 ha of farms.

The River Basin Paranapanema 4 is occupied almost entirely with artificial pastures and grasslands occurring small areas of intensive agriculture and forest coverage. The number of owners is 6.030 whose area corresponds to 479,519 ha. In this basin highlights the area of settled from the Agrarian Reform program of the federal government, amounting to 46.724 ha (the largest of the three river basins). Lessees handle with 18,521 ha (the smallest of the three river basins). It has 1,448 properties with temporary crops and area of 140.655 ha. Paranavaí is the municipality that stands in the temporary crops, because it has 443 farms (30.6\% of the total basin), with temporary crops in 32,360 ha $(23.0 \%$ of the basin).

The second city that stands out is Alto Paraná with 164 properties $(11.3 \%$ of the total basin) with temporary crops and area of 11,071 ha. (7.8\% of the basin). Permanent crops are present in 869 properties and 89,915 ha. In this basin stands out again Paranavaí which has 157 properties ( $18.1 \%$ of the basin with 23,868 ha ( $26.5 \%$ of the basin). Also noteworthy Diamante do Norte with 128 properties and 2,823 ha of permanent crops. The most significant products in planted area are firstly the Sugarcane, which highlights Cruzeiro do Sul (8,189 ha and 622,541 tons), followed by Guairaçá $(9,057$ ha and 618,617 tons) and Inajá $(5,419$ ha and 411,766 tons). Cassava has the second highest planted area, highlighting Alto Paraná (3,000 ha and 78,518 tons) and Terra Rica (2,820 ha and 73,320 tons produced) and Santo Inácio do Caiuá (1,431 ha and 33,810 tons).

The River Basin Pirapó gathers 15,176 properties, of which 12,693 properties (83.6\%) and 645,265 ha (89.3\%) are managed by the owners. In this basin is the largest area with lessees with 59,928 ha or $8.3 \%$ of the total basin area. There are also 5,574 properties $(533,460$ ha or $73.8 \%$ ) with 3,714 properties and temporary crops $(177,953$ ha or $24.6 \%)$ with permanent crops. In this basin, the municipality of Marialva has 718 properties with temporary crops and 28,197 ha and 701 farms with permanent crops and 6,131 ha. Another municipality that stands out is Apucarana with 664 properties with temporary crops $(22,726 \mathrm{ha})$ and 596 properties with permanent crops (12,276 ha). Another important municipality is Rolândia, which has 548 properties and 27,621 ha with temporary crops and Mandaguaçu with temporary crops in 329 properties totaling 5,327 ha. Among the most significant products in area and production, soybean is first (higher production) in the municipality of Arapongas, which has an area of 19,200 ha with this culture and produced 53,760 tons, followed by Apucarana (18,500 ha and produced 53,650 tons) and Astorga (17,100 ha and 51,300 tons). The Cane Sugar is the second and has the largest acreage in Colorado (15,056 ha, with 1,175,680 tons produced), followed by Jaguapitã (8,404 ha and 678,623 tons) and Lobato $(6,820$ ha and 557,262 tons) gathered.

GDP - Gross Domestic Product - which is the sum of the values generated within each municipality - total of the three River Basins is R $\$ 18,173,979$ thousand, of which $75.6 \%$ originate from the Pirapó Basin (R\$ 13,740,772 thousand), Paranapanema 3 participates with $12.9 \%$ ( $\$ 2,349,075$ thousand) and Paranapanema 4 with $11.5 \%$ ( $\$ 2,084,132$ thousand). The tertiary sector (commerce and services) in all basins stands out over $62 \%$. Draws attention that the agricultural GDP of Pirapó basin is $4.7 \%$ (IPARDES, 2012).

The basins concentrate industries that generated 6,409 on the average $\mathrm{R} \$ 321,690$ in 2010, which are highly concentrated in the Pirapó basin (5,140 establishments or $80.2 \%$ of total). Consequently, the Pirapó River Basin stands out on economic aspects of the basins by having the main city in the region, Maringá, which focuses sharply the population, employment and wealth generated in the region. A summary of the socioeconomic and environmental conditions is presented in Frame 1.

In general, the socioeconomic data released by the competent agencies indicate the characteristics of the basins and the concentration of activities and population. However, due to its lag in time, it is necessary to deepen the analysis of existing practices and their understanding of the environmental problems related to water resources in the cities studied. For this, we carried out a field research, whose methodology is presented below.

\section{Methodology}

The methodology includes three stages: (a) the classification of municipalities in the respective river basins analyzed; (b) the elaboration of a database for analysis of the general characteristics and the calculating of samples; (c) sampling and application of a questionnaire.

\subsection{The classification of municipalities in the appropriate river basin}

To perform the classification of municipalities in the River Basins, we use the data provided by the State Department of Environment (SEMA) and the Environmental Institute of Paraná - IAP/PR (PARANÁ, 2010), which allowed us to evaluate the amount and size of the municipalities located in more than one basin, because a municipality may be in two basins (such as the municipality of Colorado that has $88 \%$ of its land in Pirapó Basin and $12 \%$ in the Paranapanema 3). After discussion in the research group, we adopted the criterion that a municipality would be framed in the basin that contained more than $50 \%$ of their land. For the example shown, Colorado was within 


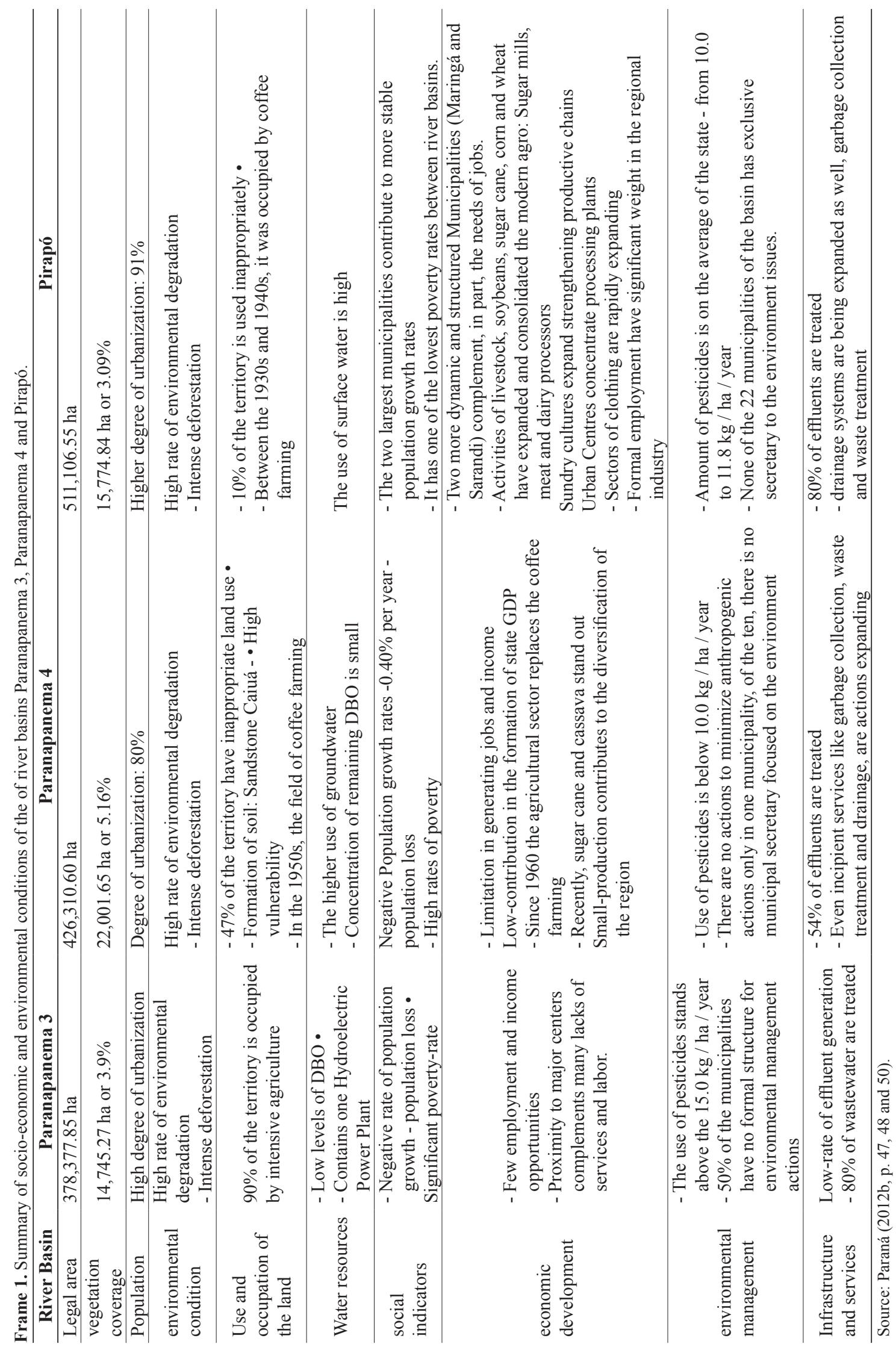


the Pirapó the Basin. The situation of belonging to more than one basin occurred in the following municipalities: Colorado; Cruzeiro do Sul, Guairaçá, Itaguajé, Jaguapitã, Jardim Olinda, Marialva, Nossa Senhora das Graças, Nova Esperança, Paranacity, Paranapoema, Rolândia, Santa Ines (located in the three river basins) and Uniflor.

As a final result, the amount and municipalities by Basin are:

a) River Basin Paranapanema 3 (total of 15 municipalities): Alvorada do Sul, Bela Vista do Paraíso, Cafeara, Cambé, Centenário do Sul, Florestópolis, Guaraci, Lupionópolis, Miraselva, Nossa Senhora das Graças, Porecatu, Prado Ferreira, Primeiro de Maio, Santa Inês and Santo Inácio. The total area is $3,776 \mathrm{~km}^{2}$;

b) River Basin Paranapanema 4 (15 municipalities): Alto Paraná, Cruzeiro do Sul, Diamante do Norte, Guairaçá, Inajá, Itaúna do Sul, Jardim Olinda, Loanda, Nova Esperança, Nova Londrina, Paranapoema, Paranavaí, Santo Antonio do Caiuá, São João do Caiuá, Terra Rica. The total area in this basin is $4,183 \mathrm{Km}^{2}$;

c) River Basin Pirapó (26 municipalities): Ângulo, Apucarana, Arapongas, Astorga, Atalaia, Cambira, Colorado, Florida, Iguaraçu, Itaguajé, Jaguapitã, Jandaia do Sul, Lobato, Mandaguaçu, Mandaguari, Marialva, Maringá, Munhoz de Melo, Paranacity, Pitangueiras, Presidente Castelo Branco, Rolândia, Sabáudia, Santa Fé, Sarandi, Uniflor. The total area in this basin is $5,067 \mathrm{Km}^{2}$.

d) Elaboration of a database and the calculating of samples

The development of a database of socio-economic and environmental data (urban and rural) was based on data provided by the Brazilian Institute of Geography and Statistics (IBGE, 2012) and the Statistical Notes of the Paraná Institute of Economic and Social Development (IPARDES, 2012).
As it was intended to conduct a field research and attempt to bringing the economic issues to an understandable level to all members of the group, we have done several meetings in order to address the various fields of study (as a multidisciplinary project). The first trial was conducted with the staff from Geography, in which it was decided to choose the cities for field research based on the way of dependence of water resources.

For that, we collected data from the National Water Agency (ANA, 2012), about the catchment points of raw water for the water supply to the urban sector. With this, the municipalities were characterized by the source of supply (underground, surface or mixed), the system (integrated or isolated) and which sub-basin are supplied. These data were compared with the population, the industrial GDP, agricultural GDP, GDP per capita, per capita income. We carried out several tests and not come to any conclusion. Then we tried to differentiate by use of surface water or groundwater resources, which also failed to differentiate. We conclude that there is a set of factors (economic activities, total population, GDP and GDP per capita) that reinforce or were reinforced by soil type and therefore interfere with the demand of water resources. What can be said is that the greater the activity and the largest concentrated population, the greater the demand. Table 1 presents some data by basin.

It was found that in all municipalities of the studied Basins, the supply of water resources exceeds existing demand. The problem encountered is regarded to the access, because in some municipalities investments in infrastructure to expand the supply of services is needed. Whereas both the form of use of water resources as the availability did not differentiate municipalities basins, further meetings occurred at the research group.

\subsection{Sampling and application of a questionnaire}

In the third phase, a range of factors led to the choice of municipalities. It was decided to select three municipalities in each basin, while in the Pirapó Basin, four municipalities were selected because, necessarily, by the historical studies conducted by the group, Maringa should be included.

Table 1. Availability and demand for water - River Basins of Pirapó, Paranapanema 3 and Paranapanema 4.

\begin{tabular}{lccc}
\hline \multicolumn{1}{c}{ Variables } & Paranapanema 3 & Paranapanema 4 & Pirapó \\
\hline Number Municipalities & 15 & 15 & 26 \\
\hline Área calculada da bacia $\left(\mathrm{Km}^{2}\right)$ & $3,318.93$ & $3,787.18$ & $4,585.16$ \\
\hline $\begin{array}{l}\text { Surface water availability } \\
(2004)\end{array}$ & $16,5801 / \mathrm{s}$ & $19,859 \mathrm{l} / \mathrm{s}$ & $30,0471 / \mathrm{s}$ \\
\hline $\begin{array}{l}\text { Underground water availability } \\
\text { (Guarani aquifer, Serra } \\
\text { Geral e Caiuá) }\end{array}$ & $\begin{array}{c}\text { (Guarani aquifer, e } \\
\text { Caiuá) }\end{array}$ & $\begin{array}{c}\text { (Guarani aquifer, Serra } \\
\text { Geral e Caiuá) }\end{array}$ \\
\hline $\begin{array}{l}\text { Motal Demand } \\
\text { expansion }\end{array}$ & Bela vista do Paraíso e \\
Cambé & 550.3 & Alto Paraná e Loanda, & $\begin{array}{c}\text { Arapongas, Colorado, } \\
\text { Jandaia do Sul, } \\
\text { Mandaguari e Rolândia }\end{array}$ \\
\hline
\end{tabular}

Source: Paraná (2012b, p. 47, 48 and 50). 
In addition, as a determinant, it was decided in a meeting of the group of researchers that the link the various studies would be the points of hydrological data collection done by the Group of Chemical Engineering and Geography.

According to information exchanged among researchers in Paranapanema 3 there are three collection points. Regarding drainage density, municipalities that interfere with point 1 are Rolândia and Cambé. Point 2 is also influenced by these municipalities, and Prado Ferreira and Bela Vista do Paraíso. The collection point 3 is directly influenced by Miraselva and Guaraci. Then there was the choice of Miraselva, Bela Vista do Paraíso and Cambé.

In the river basin Paranapanema 4, municipalities that interfere with each collection point is at point 1: Nova Esperança, Alto Paraná and Cruzeiro do Sul; at point 2: Uniflor, Paranacity and Santo Antônio do Caiuá, in addition to the previous (P1) and in the point 3 include Paranavaí, Guairaçá and Terra Rica. Thus, Paranavaí and Terra Rica interfere in the same collection point (P3); whereas Paranavai has higher drainage density. Was chosen, therefore, Alto Paraná, Paranavaí and Terra Rica.

For the Pirapó river basin, depending on the monitored points picked up Paranacity, Arapongas, Maringá (the municipality that most contributed to the decline in water quality of the River Pirapó) and considering that the River Bandeirantes do Norte is the main tributary of Pirapó interfering in some sites, we chose Colorado.

From the choice of the 10 municipalities the sample based on the number of households was calculated using the Formula 1:

$$
n=\frac{N \cdot Z^{2} \cdot p \cdot(1-p)}{Z^{2} \cdot p \cdot(1-p)+\mathrm{e}^{2} \cdot(N-1)}
$$

where:

$\mathrm{n}$ - Calculated sample;

$\mathrm{N}$ - Households in the municipality (urban and rural);

$\mathrm{Z}$ - Confidence level $=95 \%=1.96$;

$\mathrm{p}$ - Probability of the event $=50 \%$;

e - Sample error $=5 \%$.

As a result, we constructed Table 2 .

In parallel, we prepared a questionnaire that was applied in December 2012, with 50 families of elementary school students in Elementary School Marechal Floriano Peixoto, in the district named Floriano belonging to the city of Maringa. Considering the results obtained, it suffered a series of adjustments that were made in the research team meetings.

Between July and October 2013, the questionnaire was applied in 10 municipalities. We conducted 639 interviews in the urban area covering 1,735 people and 78 in a rural area that comprised 215 people, amounting to 717 questionnaires and 1,813 respondents.

The data collected were systematized into a database in an Excel spreadsheet. The results are shown below.

\section{Results and Discussion}

This section was divided into two parts: a) demographic and social aspects of the interviewed families of elected municipalities in each river basin and b) rural and environmental aspects. We point out that it was not always possible to separate these contents, as, for example, in rural areas they were closely related.

Table 2. Number of urban and rural domicile selected by municipality.

\begin{tabular}{|c|c|c|c|c|}
\hline Municipality. & $\mathrm{N}^{0}$ domicile urban & $\mathbf{N}^{0}$ Quest. urban & $\begin{array}{c}\mathrm{N}^{0} \text { domicile } \\
\text { Rural }\end{array}$ & $\mathbf{N}^{0}$ Quest. Rural \\
\hline \multicolumn{5}{|l|}{ Paranapanema 3} \\
\hline Bela Vista do Paraiso & 5,025 & 66 & 411 & 6 \\
\hline Cambé & 31,589 & 67 & 2,055 & 5 \\
\hline Miraselva & 502 & 48 & 185 & 18 \\
\hline Sub-total & 32,029 & 181 & 2,651 & 29 \\
\hline \multicolumn{5}{|l|}{ Paranapanema 4} \\
\hline Alto do Paraná & 3,836 & 59 & 865 & 13 \\
\hline Paranavaí & 27,304 & 69 & 1,607 & 4 \\
\hline Terra Rica & 4,397 & 57 & 1,138 & 15 \\
\hline Sub-total & $\mathbf{3 5 , 5 3 7}$ & 185 & 3,610 & 32 \\
\hline \multicolumn{5}{|l|}{ Pirapó } \\
\hline Arapongas & 35,203 & 71 & 941 & 2 \\
\hline Colorado & 7,437 & 66 & 683 & 6 \\
\hline Maringá & 127,011 & 72 & 2,453 & 1 \\
\hline Paranacity & 3,191 & 64 & 380 & 8 \\
\hline Sub-total & 172,842 & 273 & 4,457 & 17 \\
\hline TOTAL & 240,408 & 639 & 10,718 & 78 \\
\hline
\end{tabular}

Source: Prepared by the authors based on IBGE (2012). 


\subsection{Demographic and social aspects}

According to IBGE (2012), the area of the municipalities studied in the three basins is $4760.98 \mathrm{Km}^{2}$, of which most are located in Paranapanema 4 (48.6\% of total) and the lowest is in Paranapanema 3 (17, 4\% of total).

The population is composed of 717,970 inhabitants, mostly living in the Basin Pirapó (493,822 inhabitants or $68.8 \%$ ). The municipalities are highly urbanized (with an average of $96.5 \%$ ) and the smallest degree of urbanization observed (91.7\%) is in Paranapanema 4 and higher degree in Pirapó basin (97.8\%). This situation appears to be stronger than the Paraná average, which is $85.3 \%$. In all basins, the female population is larger than the male, and this situation is sharper in the Pirapó River Basin (51.6\%), as shown in Table 3. Spite of this relative homogeneity of the data, the distribution of variables was unequal between municipalities of the Basins, as shown in the same Table 3.

As can be observed, there is a municipality in each basin which has the largest share of total and urban population: the municipality that stands out in the basin Paranapanema 3 is Cambé ( $85.1 \%$ of the total population and $85.6 \%$ of the urban population of the river basin); in Paranapanema 4 is Paranavaí (73.9\% of the total and $76.7 \%$ of urban) and in the Pirapó Basin is Maringá (72.3\% of the total and $98.2 \%$ of the urban population), pointing to the fact that environmental problems arise or are accentuated from some municipalities, which concentrate not only the population but also the industries and farms, a reflection of increased job and development opportunities in the region.

There are differences not only between basins as well as within each basin. In the Paranapanema 3 Miraselva has
$76.8 \%$ of the urban population while Cambé has $96.1 \%$. In the basin Paranapanema 4, the degree of urbanization varies from $81.3 \%$ (Terra Rica) to $95.3 \%$ (Paranavaí). In the Pirapó basin this variation is smaller, ranging between 92.4\% (Paranacity) and 98.2\% (Maringá).

When comparing the average number of inhabitants per household (IBGE, 2012) with those found in the field research, presented in Table 4, the average is 2.8 people per household in Paraná and in the region of study such average is 2.7 people per household. However, the differences are accentuated.

Regarding the urban data, we have the following information in Table 4.

As can be observed, 639 families were interviewed. Of these, $71.2 \%$ (455 families) owned their own house and $28.3 \%$ (181 families) rented their houses. The analysis by basins reveals that the percentage of households with own house range: a) in the Paranapanema 3 is $79.0 \%$ (143 families); b) in the Paranapanema 4 is $63.8 \%$ (118 families) and c) in Pirapó is 71.1\%. (194 families). The families numbered 1,725 inhabitants, of whom 525 (30.4\%) were in Paranapanema 3; Paranapanema 4 concentrated 433 people $(25.1 \%)$ and 767 inhabitants (44.5\%) were in Pirapó.

In addition, $5.6 \%$ of respondents are illiterate and the highest percentage is in Paranapanema 3 (6.3\%); further $26.5 \%$ had incomplete primary education (458 people) and the highest percentage is in Paranapanema 4 (31.9\%) and $17.6 \%$ (303 people) had completed elementary school, ranging $22.6 \%$ in the Paranapanema 4 . The complete and incomplete secondary education corresponds to $33.9 \%$

Table 3. Current, urban and rural, male and female population of the selected municipalities of River Basins Paranapanema 3 and 4 and Pirapó River Basin - 2010.

\begin{tabular}{llrrrrrrc}
\hline \multicolumn{1}{c}{$\begin{array}{c}\text { Municipalities } \\
\text { Basins }\end{array}$} & $\begin{array}{c}c \\
\text { Pop. } \\
\text { current }\end{array}$ & \% & $\begin{array}{c}\text { Pop. } \\
\text { urban }\end{array}$ & $\begin{array}{c}\text { Distrib. } \\
\text { Pop. }\end{array}$ & $\begin{array}{c}\text { Degree } \\
\text { urban }\end{array}$ & $\begin{array}{c}\text { Pop. } \\
\text { rural }\end{array}$ & $\begin{array}{c}\text { Pop. } \\
\text { Fem. }\end{array}$ & $\begin{array}{c}\text { Pop. } \\
\text { masc. }\end{array}$ \\
\hline Paranapanema 3 & & & & & & & & \\
Bela Vista do & 15,079 & 13.3 & 14,196 & 13.1 & 94.1 & 883 & 7,762 & 7,317 \\
Paraíso & & & & & & & & \\
Cambé & 96,733 & 85.1 & 92,952 & 85.6 & 96.1 & 3,781 & 49,434 & 47,299 \\
Miraselva & 1,862 & 1.6 & 1,430 & 1.3 & 76.8 & 432 & 939 & 923 \\
Subtotal P3 & 113,674 & 100.0 & 108,578 & 100.0 & 95.5 & 5,096 & 58,135 & 55,539 \\
Paranapanema 4 & & & & & & & & \\
Alto Paraná & 13,663 & 12.4 & 11,221 & 11.1 & 82.1 & 2,442 & 6,821 & 6,842 \\
Paranavaí & 81,590 & 73.9 & 77,728 & 76.7 & 95.3 & 3,862 & 42,308 & 39,282 \\
Terra Rica & 15,221 & 13.7 & 12,370 & 12.2 & 81.3 & 2,851 & 7,612 & 7,609 \\
Subtotal P4 & 110,474 & 100.0 & 101,319 & 100.0 & 91.7 & 9,155 & 56,741 & 53,733 \\
Pirapó & & & & & & & & \\
Arapongas & 104,150 & 21.1 & 101,851 & 21.1 & 97.8 & 2,299 & 53,111 & 51,039 \\
Colorado & 22,345 & 4.5 & 21,005 & 4.3 & 94.0 & 1,340 & 11,303 & 11,042 \\
Maringa & 357,077 & 72.3 & 350,653 & 72.6 & 98.2 & 6,424 & 185,353 & 171,724 \\
Paranacity & 10,250 & 2.1 & 9,469 & 2.0 & 92.4 & 781 & 5,135 & 5,115 \\
Subtotal PI & 493,822 & 100.0 & 482,978 & 100.0 & 97.8 & 10,844 & 254,902 & 238,920 \\
TOTAL & 717,970 & & 692,875 & & 96.5 & 25,095 & 369,778 & 348,192 \\
\hline
\end{tabular}

Source: IBGE (2012). 
Table 4. Characteristics of urban households by family and formal education of people in the selected municipalities -2013 .

\begin{tabular}{|c|c|c|c|c|c|c|c|c|c|c|c|c|}
\hline \multirow[b]{2}{*}{ Munic. } & \multicolumn{3}{|c|}{ Family } & \multicolumn{9}{|c|}{ People } \\
\hline & PP & $\mathbf{A L}$ & $\mathbf{O}$ & Analf & $\begin{array}{c}\text { F } \\
\text { Inc. }\end{array}$ & $\begin{array}{c}\mathbf{F} \\
\text { com }\end{array}$ & $\begin{array}{c}\text { M } \\
\text { Inc. }\end{array}$ & $\begin{array}{c}\text { M } \\
\text { Com }\end{array}$ & $\begin{array}{c}\text { S } \\
\text { Inc }\end{array}$ & $\begin{array}{c}\mathrm{S} \\
\text { com }\end{array}$ & NR & TOTAL \\
\hline Paranapanem & & & & & & & & & & & & \\
\hline $\begin{array}{l}\text { B.V. } \\
\text { Paraíso }\end{array}$ & 54 & 12 & & 11 & 63 & 20 & 21 & 50 & 6 & 20 & 5 & 196 \\
\hline Cambé & 50 & 16 & 1 & 14 & 41 & 35 & 21 & 50 & 9 & 28 & 5 & 203 \\
\hline Miraselva & 39 & 9 & & 8 & 29 & 15 & 10 & 33 & 9 & 21 & 1 & 126 \\
\hline subtotal & 143 & 37 & 1 & 33 & 133 & 70 & 52 & 133 & 24 & 69 & 11 & 525 \\
\hline Paranapanem & & & & & & & & & & & & \\
\hline Alto Paraná & 30 & 29 & & 4 & 43 & 40 & 4 & 20 & 7 & 15 & & 133 \\
\hline Paranavaí & 42 & 26 & 1 & 13 & 47 & 27 & 9 & 40 & 10 & 19 & 1 & 166 \\
\hline Terra Rica & 46 & 11 & & 2 & 48 & 31 & 11 & 25 & 9 & 8 & & 134 \\
\hline Subtotal & 118 & 66 & 1 & 19 & 138 & 98 & 24 & 85 & 26 & 42 & 1 & 433 \\
\hline Pirapó & & & & & & & & & & & & \\
\hline Arapongas & 55 & 16 & & 14 & 55 & 29 & 28 & 51 & 13 & 10 & 6 & 206 \\
\hline Colorado & 49 & 16 & 1 & 17 & 40 & 35 & 22 & 50 & 10 & 20 & 1 & 195 \\
\hline Maringa & 48 & 24 & & 6 & 51 & 37 & 28 & 48 & 9 & 14 & 8 & 201 \\
\hline Paranacity & 42 & 22 & & 7 & 41 & 34 & 32 & 32 & 3 & 14 & 2 & 165 \\
\hline Subtotal & 194 & 32 & 1 & 44 & 187 & 135 & 110 & 181 & 35 & 58 & 17 & 767 \\
\hline TOTAL & 455 & 181 & 3 & 96 & 458 & 303 & 186 & 399 & 85 & 169 & 29 & 1,725 \\
\hline
\end{tabular}

Obs: $\mathrm{PP}=$ own house; $\mathrm{AL}=$ rented; $\mathrm{O}=$ other; $\mathrm{AS}=$ settler; Analf = iliterate; inc = incomplete; $\mathrm{Com}=$ complete; $\mathrm{F}=$ primary school; $\mathrm{M}=$ high school; $\mathrm{S}=$ higher education; $\mathrm{NR}=$ not answered. Source: field research (2013).

(585 eople) and Pirapó is the highest percentage (37.9\%). The respondents that had finished the graduation correspond to $14.7 \%$ (254 people) and the largest percentage is located in Paranapanema 3 (17.7\%).

This latter result is surprising because, in Pirapó lies the city of Maringá, an educational hub, as it concentrates 8 colleges and a state university, which should be reflected in the results. Another aspect that stands out is that the largest number of people with complete or incomplete higher education in the basin is concentrated in Maringa (almost 50\%), which shows the concentrating characteristic of the municipality.

The average number of persons per household is presented in Table 5, in a comparison between IBGE Cidades (IBGE, 2012) with the field research.

The field research shows that both the Paranapanema 3 as the Pirapó follow values of the IBGE to the average and urban sector and are quite different for the rural sector, thus, are significantly higher (2,7 in Paranapanema 3 and 2.8 in Pirapó). This situation may indicate a process of population retention or return to their rural areas, which needs to be further explored in future population surveys. In the case of Paranapanema 4 data collected are presented quite different: the average and the urban sector are below and to the rural sector presents similar, which may indicate a process of expulsion / migration, which also deserves further investigation.

It was also verified by the data collected that the average population per household is higher in rural areas than in the urban sector in all of the municipalities surveyed in Pirapó and Paranapanema 4. In Paranapanema 3, the exception is Bela Vista do Paraíso. These data are similar to the consensus that there is a greater number of children per inhabitant in the rural sector.

Regarding poverty we chose to use the latest data of the number of families who register and receive the Bolsa Família $^{1}$, because can only be on the federal government program those who are poor or live in extreme poverty. We alert that these data differ from those found in the 2010 Census. As a result, it is presented the Table 6. This table shows the total number of families and people of the municipalities surveyed, the number of registered families which receive up to $\mathrm{R} \$ 70.00$ (extreme poverty) and those who earned between R\$ 70.00 and R\$ 140.00 (poor) so as the number of beneficiaries, the average payment and the number of people surveyed who receive the Bolsa Família or other government support (milk, electricity, PETI). In the field research, with the exception of Alto Paraná, in all municipalities, we interviewed people who receive Bolsa Família.

According to the data of Table 6, the number of poor families and individuals and extreme poverty is alarming. Furthermore, the beneficiaries of Bolsa Família are concentrated in the urban sector, because only in Cambé (1 family) and Miraselva ( 3 families) were registered beneficiaries in the rural sector. According to the Ministry of Social Development and Fight against Hunger (BRASIL, 2013a) in all municipalities of the Basins there are percentages approaching $50 \%$ of households in the municipality as beneficiaries of the income transfer program of the federal

\footnotetext{
1 The Bolsa Família Program is a program of direct income transfer conducted by Brazil's federal government that benefits families in poverty and extreme poverty across the country.
} 
Table 5. Average people per household, the total, urban and rural.

\begin{tabular}{|c|c|c|c|c|c|c|}
\hline \multirow[b]{2}{*}{ Municipalities } & \multicolumn{3}{|c|}{ IBGE } & \multicolumn{3}{|c|}{ Observed } \\
\hline & $\begin{array}{c}\text { Average } \\
\text { total }\end{array}$ & $\begin{array}{c}\text { Average } \\
\text { urban }\end{array}$ & $\begin{array}{c}\text { Average } \\
\text { rural }\end{array}$ & $\begin{array}{c}\text { Average } \\
\text { total }\end{array}$ & $\begin{array}{c}\text { Average } \\
\text { urban }\end{array}$ & $\begin{array}{c}\text { Average } \\
\text { rural }\end{array}$ \\
\hline \multicolumn{7}{|l|}{ Paranapanema 3} \\
\hline B.Vi.Paraíso & 2.8 & 2.8 & 2.1 & 2.9 & 3.0 & 2.3 \\
\hline Cambé & 2.9 & 2.9 & 1.8 & 3.1 & 3.0 & 3.6 \\
\hline Miraselva & 2.7 & 2.8 & 2.3 & 2.6 & 2.6 & 2.6 \\
\hline Subtotal & 2.9 & 2.9 & 1.9 & 2.9 & 2.9 & 2.7 \\
\hline \multicolumn{7}{|l|}{ Paranapanema 4} \\
\hline Alto Paraná & 2.9 & 2.9 & 2.8 & 2.4 & 2.3 & 3.0 \\
\hline Paranavaí & 2.8 & 2.8 & 2.4 & 2.4 & 2.4 & 1.8 \\
\hline Terra Rica & 2.7 & 2.8 & 2.5 & 2.3 & 2.4 & 2.3 \\
\hline Subtotal & 2.8 & 2.9 & 2.5 & 2.4 & 2.3 & 2.5 \\
\hline \multicolumn{7}{|l|}{ Pirapó } \\
\hline Arapongas & 2.9 & 2.9 & 2.4 & 2.9 & 2.9 & 3.0 \\
\hline Colorado & 2.8 & 2.8 & 2.0 & 3.0 & 3.0 & 3.5 \\
\hline Maringá & 2.8 & 2.8 & 2.6 & 2.8 & 2.8 & 4.0 \\
\hline Paranacity & 2.9 & 3.0 & 2.1 & 2.6 & 2.6 & 3.0 \\
\hline Subtotal & 2.8 & 2.8 & 2.4 & 2.8 & 2.8 & 3.2 \\
\hline TOTAL & 2.8 & 2.8 & 2.3 & 2.7 & 2.7 & 2.8 \\
\hline
\end{tabular}

Source: IBGE Cidades (IBGE, 2012) and field research (2013).

government, such as: (a) in Paranapanema 3: Bela Vista do Paraíso (49.4\% of the families and $54.9 \%$ of the inhabitants) and Miraselva (47.3\% of the families and $55.7 \%$ of the people); (b) in Paranapanema 4: Alto Paraná (37.9\% of the families and $43.4 \%$ of the individuals), Terra Rica (48.8\% of the families and $55.0 \%$ of the inhabitants) and (c) in Pirapó: Arapongas (46.3\% of the families and $43.7 \%$ of the people) and Paranacity (39.4\% of the households and $44.5 \%$ of the inhabitants). The lowest percentages are in Pirapó in the municipalities of Colorado (14.7\% of the households and $17.7 \%$ of the inhabitants) and Maringá ( $20.2 \%$ of the families and $21.6 \%$ of the people), which points to different dynamics and conditions in these municipalities.

When analyzing the number of registered persons and beneficiaries, in the Table 6 , it is not possible to identify a direct relationship, i.e., not necessarily the larger the number of poor people more benefits. Apparently, the number of registrations has greater weight, but this needs to be researched more thoroughly, because the information to identify if all who are in extreme poverty have been benefited by the program is not available.

Another point that stands out is that some municipalities that have higher percentages of registered families with income up to R $\$ 70.00$ per capita (such as Cambé $-23.1 \%$ in Paranapanema 3; Alto Paraná-32.4\% and Paranavai-26.6\% in Paranapanema 4 and Paranacity $-22.6 \%$ in Pirapó), in which, although there is high rate of extreme poverty among registered families, these municipalities are not always receiving higher amount of beneficiaries or benefits.

There are also coincident cases of major beneficiaries, such as Cambé (82.2\%), Alto Paraná (20.9\%), Paranavaí
(68.6\%), but also Maringa (63.2\%), which has lower rate compared with the other. The poverty rate in Paranapanema 3 represents $6.2 \%$ of total households in the basin and, by all indications, public policies contribute very little to the generation of jobs and income.

With regard to access to welfare, all households in which interviews were conducted have electricity in both the rural and the urban sector. There is piped water supplies in all of the urban and rural households. However, the source of this resource is differentiated. In the urban sector, the majority of families (626 families) uses the public water supply, however the use of wells was verified as follows: (a) Paranapanema 3: Cambé- 1 family (1,5\%) and Miraselva- 6 families (13.0\%); (b) Paranapanema 4: Alto Paraná- 1 family (1.7\%) and Terra Rica- 1 family (1.8\%); (c) Pirapó: Colorado- 2 families (3.0\%) and Maringá- 2 families (2.8\%).

In the rural sector, all households have piped water drawn from wells, except in Paranapanema 3, the municipalities of Cambé (which has 2 families who use public system of water and 1 family that uses the river) and Miraselva (1 family that uses public water supply). In the basin of Pirapó both Arapongas ( 2 families) and Colorado ( 2 families) beyond the well also use river water. The situation of the interviewed families that do not have sewer is worrying, as shown in Table 7.

As can be observed, in the rural sector, not all families are served by sewage treatment and, as seen above, all draw water from wells, which present risks to both human health and for the environment, including water resources.

It is noteworthy that all basins and municipalities are above average provided by IPARDES (2013, p. 225), 


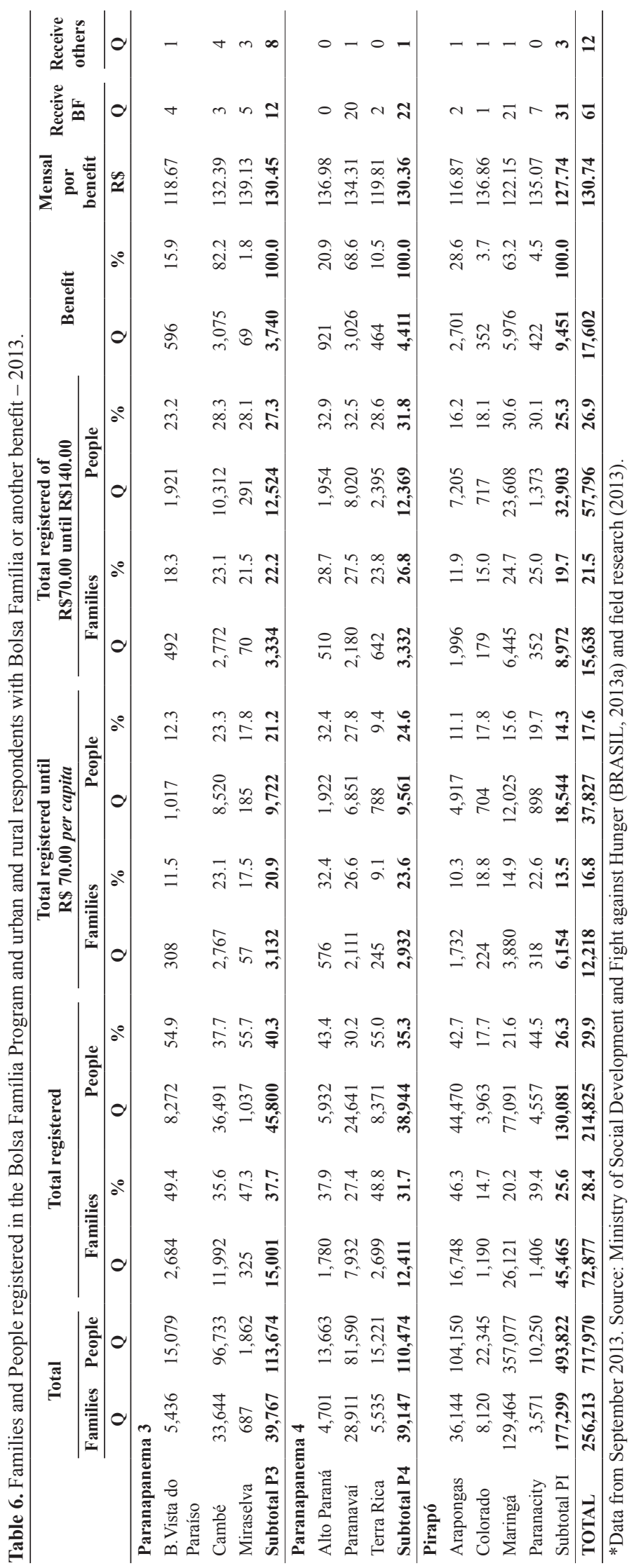


which is to Paranapanema 3 with $37.2 \%$ of families with treatment; Paranapanema 4 is $35.0 \%$ and in the basin of Pirapó is $42.5 \%$. Exceptions, however, are worrisome because there are municipalities with families with more than $40 \%$ non-attendance as Terra Rica and Paranacity. The situation is alarming in Miraselva because all families interviewed claimed not to have sewage treatment (do not forget that this municipality has the largest number of families who have wells, i.e., 6 from 18).

\subsection{The situation in the rural sector and the environment}

The conditions of possession of the house and educational level are presented in Table 8.

The Table shows that from the 78 families interviewed, most of them have their own property $(87.2 \%)$, 7 were tenants $(9.0 \%)$ and two were sharecroppers $(2.6 \%)$ and one was settler $(1.2 \%)$. In the Pirapó river basin, all families have their own property. We found other conditions in all

Table 7. Presence of sewage treatment, urban and rural sector -2013.

\begin{tabular}{|c|c|c|c|c|c|c|}
\hline \multirow{2}{*}{ Municipality } & \multicolumn{4}{|c|}{ Urban } & \multicolumn{2}{|c|}{ Rural } \\
\hline & Yes & $\%$ Yes & Not & $\%$ Not & Yes & Not \\
\hline \multicolumn{7}{|l|}{ Paranapanema 3} \\
\hline Bela Vista do Paraíso & 44 & 66.7 & 22 & 33.3 & & 6 \\
\hline Cambé & 60 & 89.6 & 7 & 10.4 & & 5 \\
\hline Miraselva & 0 & 0 & 48 & 100.0 & & 18 \\
\hline Sub-total & 104 & 57.5 & 77 & 42.5 & $\mathbf{0}$ & 29 \\
\hline \multicolumn{7}{|l|}{ Paranapanema 4} \\
\hline Alto Paraná & 49 & 83.1 & 10 & 16.9 & & 13 \\
\hline Paranavaí & 62 & 89.9 & 7 & 10.1 & & 4 \\
\hline Terra Rica & 32 & 56.1 & 25 & 43.9 & & 15 \\
\hline Sub-total & 143 & 77.3 & 42 & 22.7 & 0 & 32 \\
\hline \multicolumn{7}{|l|}{ Pirapó } \\
\hline Arapongas & 56 & 78.9 & 15 & 21.1 & & 2 \\
\hline Colorado & 58 & 87.9 & 8 & 12.1 & & 6 \\
\hline Maringa & 62 & 86.1 & 10 & 13.9 & & 1 \\
\hline Paranacity & 38 & 59.4 & 26 & 40.6 & & 8 \\
\hline Sub-total & 214 & 78.4 & 59 & 21.6 & $\mathbf{0}$ & 17 \\
\hline
\end{tabular}

Source: Field research (2013).

Table 8. Characteristics of rural households by family and formal education by municipality -2013 .

\begin{tabular}{|c|c|c|c|c|c|c|c|c|c|c|c|c|}
\hline \multirow[b]{2}{*}{ Municipalities } & \multicolumn{4}{|c|}{ Domicile rurais } & \multicolumn{7}{|c|}{ Schooling of people } & \multirow[b]{2}{*}{ TOTAL } \\
\hline & $\mathbf{P P}$ & $\mathbf{A R}$ & PC & AS & Analf & $\begin{array}{c}\text { F. } \\
\text { Inc. }\end{array}$ & $\begin{array}{c}\text { F. } \\
\text { Com }\end{array}$ & $\begin{array}{c}\text { M. } \\
\text { Inc. }\end{array}$ & $\begin{array}{c}\text { M } \\
\text { Com. }\end{array}$ & $\begin{array}{c}\text { S. } \\
\text { Inc. }\end{array}$ & $\begin{array}{c}\text { S. } \\
\text { Com. }\end{array}$ & \\
\hline \multicolumn{13}{|l|}{ Paranapanema 3} \\
\hline B.V.Paraíso (6) & 5 & 1 & & & 2 & 3 & 3 & 1 & 5 & & & 14 \\
\hline Cambe (5) & 4 & 1 & & & 0 & 8 & 6 & 1 & 2 & 0 & 1 & 18 \\
\hline Miraselva (18) & 16 & 1 & 1 & & 4 & 23 & 8 & 4 & 7 & 0 & 1 & 47 \\
\hline Subtotal (29) & 25 & 3 & 1 & & 6 & 34 & 17 & 6 & 14 & $\mathbf{0}$ & 2 & 79 \\
\hline \multicolumn{13}{|l|}{ Paranapanema 4} \\
\hline Alto Paraná (13) & 12 & & & 1 & 6 & 7 & 12 & 1 & 9 & 3 & 1 & 39 \\
\hline Paranavaí (4) & 4 & & & & & 1 & 3 & 1 & 2 & & & 7 \\
\hline Terra Rica (15) & 10 & 4 & 1 & & 2 & 13 & 8 & 7 & 2 & 2 & 1 & 35 \\
\hline subtotal (32) & 26 & 4 & 1 & 1 & 8 & 21 & 23 & 9 & 13 & 5 & 2 & 81 \\
\hline \multicolumn{13}{|l|}{ Pirapó } \\
\hline Arapongas (2) & 2 & & & & & & 4 & & 1 & & 1 & 6 \\
\hline Colorado (6) & 6 & & & & & 4 & 5 & 4 & 7 & & 1 & 21 \\
\hline Maringá (1) & 1 & & & & 1 & 1 & 1 & & 1 & & & 4 \\
\hline Paranacity (8) & 8 & & & & 1 & 7 & 9 & 3 & 3 & 1 & & 24 \\
\hline subtotal (17) & 17 & $\mathbf{0}$ & $\mathbf{0}$ & & 2 & 12 & 19 & 7 & 12 & 1 & 2 & 55 \\
\hline TOTAL (78) & 68 & 7 & 2 & 1 & 16 & 67 & 59 & 22 & 39 & 6 & 6 & 215 \\
\hline
\end{tabular}

Obs: $\mathrm{PP}=$ own property; $\mathrm{AR}=$ leaseholder; $\mathrm{PC}=$ sharecroppers; $\mathrm{AS}=$ settler; Analf = iliterate; inc = incomplete; Com = complete; $\mathrm{F}=$ primary school; $\mathrm{M}=$ high school; $\mathrm{S}=$ higher education. Source: Field research (2013). 
municipalities of Paranapanema 3 (presence of tenants and sharecroppers). In the basin of Paranapanema 4 only Terra Rica has recorded the presence of tenants and sharecroppers. In Alto Paraná only one settler was interviewed.

The respondent families aggregate 215 people, 79 of whom were in Paranapanema 3; 81 in the Paranapanema 4 and in the Pirapó 55 people. Out of this total, 16 (7.4\%) are illiterate and the highest percentage is in Paranapanema $3(6.3 \%)$; further $26.5 \%$ had incomplete primary education (458 people) and the highest percentage is in Paranapanema $4(50.0 \%)$.

We found $27.4 \%$ of the respondents (59 people) with complete primary education while the highest percentage is in Paranapanema 4 (39.0\%). The complete and incomplete secondary education corresponds to $28.4 \%$ (61 people) and and in the Pirapó is the highest percentage (34.5\%). The complete and incomplete higher education corresponds to $5.5 \%$ (12 people) while the highest percentage is located in Paranapanema 4 (8.6\%). Once again, this last result is surprising because in the Pirapó lies the city of Maringá, an educational hub. Another aspect that draws attention is that in Maringa there is no presence of people with complete or incomplete higher education. In the rural case, we find more people with the completed elementary school and lower values for education levels of high school and higher education.

The practices of the rural sector are result and dependent on the history of the region characterized by the green revolution and the introduction of heavy machinery and equipment, high technology and intensive livestock farming introduced in regions with highly vulnerable land. As a result, the practices found by the field research are presented in Table 9.

It is noteworthy that no-till farming is associated to not soil tillage, permanent coverage with organic material (reduces the use of chemical fertilizer) and crop rotation. The integrated management, in its turn, though admitting the use of chemical and biological raw materials is also associated with crop rotation (BRASIL, 2013b, p. 52). Thus, when analyzing the Table 9 we can infer the following: In the Paranapanema 3, most families conducts no-till farming (45\%), using transgenic seeds $(72 \%)$ and chemical fertilizers (48\%), makes crop rotation (48\%) and does not perform integrated management $(72 \%)$.

However some aspects draw attention: (a) all the respondents in Cambé reported using chemical fertilizer, which influenced the percentage of the basin; (b) transgenic seed is predominant in all the studied families; (c) the no-till farming predominates in Bela Vista do Paraíso and Cambé; (d) in Bela Vista do Paraíso and Cambé there were slash-and-burn farming practices ${ }^{2}$. There is some coherence in practices, because those families who perform no-till farming usually perform crop rotation too and partly perform integrated management, with the exception of

\footnotetext{
2 We cannot forget that the cultivation techniques inadequate (deforestation, deforestation and slash-and-burn techniques) accelerate the process of soil erosion.
}

Cambé (where $60 \%$ reported performing no-till farming, however only $20 \%$ do crop rotation).

Thus, Cambé seems to be the most problematic municipality because all respondents stated that they only perform chemical fertilization, although most do not perform no-till farming or crop rotation, do not use organic fertilizer and don't perform integrated management.

In the Basin Paranapanema 4 predominates organic fertilization (78\%), farmers do not use genetically modified seeds $(81.3 \%)$, the technique of no-till farming (59\%) as well as crop rotation $(65 \%)$ are made in a smaller proportion. However they do not perform the integrated management. Paranavaí stands out for presenting 100\% of no-till farming, $100 \%$ of organic fertilizers use and $100 \%$ of integrated management, although only $50 \%$ claimed to perform crop rotation.

In the Pirapó Basin no-till farming predominates (76\%) as well as crop rotation (58\%), organic fertilization (77\%) and integrated management. However, both in Colorado and in Paranacity the percentage of those who perform no-till farming and integrated management is greater than those who declare to make crop rotation. Furthermore, in Arapongas respondents use chemical and organic fertilization.

One of the toughest questions to be answered was regarding the use of transgenic seeds ${ }^{3}$, whose highest incidence occurred in the Paranapanema 3 (72.4\%) and the lowest frequency in the Pirapó (6.3\%). Regarding the pig farming, whose wastes are highly contaminating, we present the Table 10 .

There is a greater presence of pigsties in the Paranapanema 3 (51.7\% of the respondents of the basin) and Pirapo (56.3\% of the respondents of the basin). With the exception of Paranavaí, Maringá and Arapongas, whose facilities match or approximate of the number of families who perform pig farming, it is clear that the families who declare to perform any kind of swine production is greater than those who claim to have pigsties (minimal installation), because of these respondents in the three river basins sell and / or create for their own consumption, which can impact the environment. Although the nutrients present in the feces (manure) and urine of these animals have encouraged their use as organic fertilization, this procedure also present hazards of environmental contamination resulting from its storage form, distribution and use. Furthermore, hormones

\footnotetext{
3 There is still much controversy surrounding the spread of genetically modified food. The defenders argue that transgenic aggregate greater nutritional value and even eliminate some undesirable characteristics (lower cholesterol of the egg, for example) generate crops more resistant to the cold, drought and pest attacks and diseases increasing productivity. The opposites to introduce of transgenic in food argue that there is still much ignorance about the effects of genetic manipulation, which may represent a serious risk to human health and to the environment. Meanwhile, government agencies and consumer protection organizations advocate labeling of all foods that contain a genetically modified ingredient in its composition, to facilitate the identification of such products and guarantee consumers the power to decide whether to consume them or not (BRASIL, 2013b, p. 47).
} 


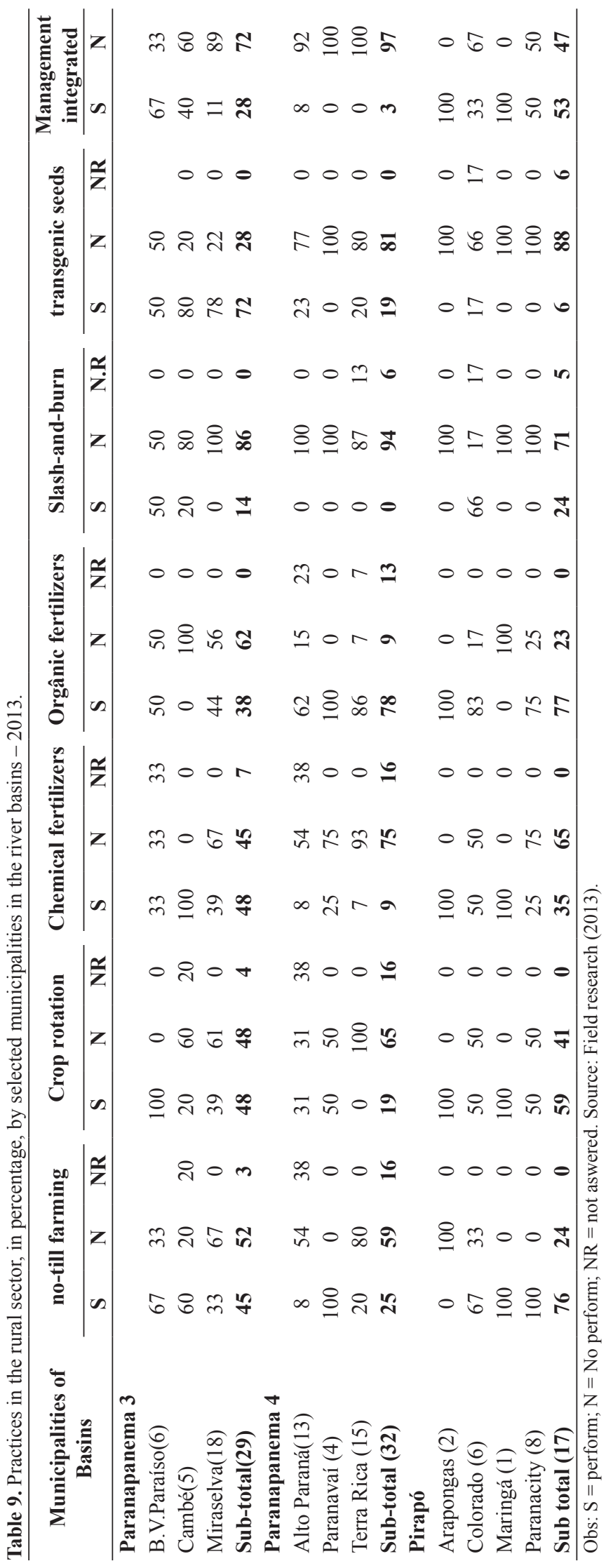


Table 10. Presence of pigsties and pig farming in the selected municipalities -2013 . Obs: $v=\mathrm{sell}$.

\begin{tabular}{|c|c|c|c|c|c|c|}
\hline \multirow{2}{*}{ Municipalities } & \multicolumn{2}{|c|}{ Pigsties } & \multicolumn{4}{|c|}{ Pig farming } \\
\hline & Yes & Not & $\mathbf{V}$ & Use & V+ Use & Not \\
\hline \multicolumn{7}{|l|}{ Paranapanema 3} \\
\hline B.V.Paraíso (6) & 33.3 & 66.7 & 0 & 3 & 3 & 0 \\
\hline Cambé (5) & 60.0 & 40.0 & 1 & 2 & 1 & 1 \\
\hline Miraselva (18) & 55.6 & 44.4 & 2 & 10 & 1 & 5 \\
\hline Sub-total (29) & 51.7 & 48.3 & 3 & 15 & 2 & 9 \\
\hline \multicolumn{7}{|l|}{ Paranapanema 4} \\
\hline Alto Paraná (13) & 7.7 & 92.3 & 1 & 1 & & 11 \\
\hline Paranavaí (4) & 25.0 & 75.0 & 0 & 1 & 0 & 3 \\
\hline Terra Rica (15) & 0.0 & 86.7 & 0 & 2 & 0 & 13 \\
\hline Subtotal (32) & 6.3 & 87.5 & 1 & 4 & $\mathbf{0}$ & 27 \\
\hline \multicolumn{7}{|l|}{ Pirapó } \\
\hline Arapongas (2) & 100.0 & 0.0 & 0 & 2 & 0 & 0 \\
\hline Colorado (5) & 20.0 & 80.0 & 3 & 2 & 1 & 0 \\
\hline Maringá (1) & 0.0 & 0.0 & 0 & 0 & 0 & 0 \\
\hline Paranacity (8) & $75.0(3 \mathrm{vd})$ & 25.0 & 2 & 1 & 4 & 1 \\
\hline Sub-total (16) & $56.3(4 \mathrm{vd})$ & 43.8 & 5 & 5 & 5 & 2 \\
\hline Total (77) & 33.8 & 66.2 & & & & \\
\hline
\end{tabular}

Source: Field research (2013).

Table 11. Practices for waste separation, recovery of riparian vegetation and septic tank -2013 .

\begin{tabular}{|c|c|c|c|c|c|c|}
\hline \multirow[t]{2}{*}{ Municipalities } & \multicolumn{2}{|c|}{ waste separation } & \multicolumn{2}{|c|}{$\begin{array}{c}\text { recovery of riparian } \\
\text { vegetation }\end{array}$} & \multicolumn{2}{|c|}{ septic $\tan k$} \\
\hline & Yes & Not & Yes & Not & Yes & Not \\
\hline \multicolumn{7}{|l|}{ Paranapanema 3} \\
\hline B.V.Paraíso (6) & 3 & 3 & 2 & 4 & 3 & 3 \\
\hline Cambé (5) & 3 & 2 & 1 & 4 & 3 & 2 \\
\hline Miraselva (18) & 4 & 14 & 2 & 16 & 13 & 5 \\
\hline Subtotal & 10 & 19 & 5 & 24 & 19 & 10 \\
\hline \multicolumn{7}{|l|}{ Paranapanema 4} \\
\hline Alto Paraná (13) & 12 & 1 & 1 & 12 & 13 & \\
\hline Paranavaí (4) & 4 & & & 4 & 4 & \\
\hline Terra Rica (15) & 7 & 8 & & 15 & 15 & \\
\hline Subtotal & 23 & 9 & 1 & 31 & 32 & $\mathbf{0}$ \\
\hline \multicolumn{7}{|l|}{ Pirapó } \\
\hline Arapongas (2) & 2 & & & 2 & 2 & \\
\hline Colorado (6) & 5 & 1 & 3 & 3 & 3 & 3 \\
\hline Maringa (1) & 1 & & & 1 & 1 & \\
\hline Paranacity (8) & 6 & 2 & & 8 & 8 & \\
\hline Subtotal & 14 & 3 & 3 & 14 & 14 & 3 \\
\hline
\end{tabular}

Obs: $\mathrm{NR}=$ not answered. Source: field research (2013).

and antibiotics can be eliminated with the feces and urine of animals, being incorporated into the soil (BRASIL, 2013b, p. 44).

Among other practices analyzed are those relating to the households (septic tanks and waste separation) and the production (recovery of riparian vegetation), as shown in Table 11.

As seen in the table, the river basin Paranapanema 3 concentrates the most troubled municipalities, because the majority does not separate waste $(65.5 \%)$, does not perform the recovery of riparian vegetation $(82.7 \%)$ and has the highest incidence of not having septic tank (34.5\%). This frame contrasts with the other municipalities of the basins in which all respondents have septic tanks, with the exception of Colorado, where only $50 \%$ have this structure.

The biggest problem in all municipalities is the non-recovery of riparian vegetation in all basins and no separation of waste. On this last issue is the identification of street cleaning by the public sector, as shown in Table 12 . 
Table 12. Frequency of cleaning of public areas on the interviewees' opinion -2013 .

\begin{tabular}{|c|c|c|c|c|c|}
\hline \multirow{3}{*}{ Municipalities } & \multicolumn{5}{|c|}{ Frequency of cleaning of public areas } \\
\hline & \multicolumn{4}{|c|}{ Yes } & \multirow[b]{2}{*}{ Not } \\
\hline & Weekly & Biweekly & Monthly & $\begin{array}{c}\text { Less than } \\
\text { once / month }\end{array}$ & \\
\hline \multicolumn{6}{|l|}{ Paranapanema 3} \\
\hline B.Vista Paraíso (6) & & 3 & 3 & & \\
\hline Cambe (5) & & 2 & 3 & & \\
\hline Miraselva (18) & 15 & & 1 & 1 & 1 \\
\hline Sub total (29) & 15 & 5 & 7 & 1 & 1 \\
\hline \multicolumn{6}{|l|}{ Paranapanema 4} \\
\hline Alto Paraná (13) & & 11 & 2 & & \\
\hline Paranavaí (4) & & 4 & & & \\
\hline Terra Rica (15) & 9 & 6 & & & \\
\hline Sub total (32) & 9 & 21 & 2 & $\mathbf{0}$ & $\mathbf{0}$ \\
\hline \multicolumn{6}{|l|}{ Pirapó } \\
\hline Arapongas (2) & 1 & & & & 1 \\
\hline Colorado (6) & 1 & & & & 5 \\
\hline Maringá (1) & & & & & 1 \\
\hline Paranacity (8) & & & & & 8 \\
\hline Sub total (17) & 2 & $\mathbf{0}$ & $\mathbf{0}$ & $\mathbf{0}$ & 15 \\
\hline
\end{tabular}

Source: Field research (2013).

As seen in the Table 12, the situations are different, but present trends. In the Paranapanema 3, the vast majority claims to have weekly cleaning, however in Bela Vista do Paraíso and Cambé cleaning is biweekly and monthly (which may depend on the location of the property). Crossing the data of Table 11 with Table 12, only 1 respondent claims not to have public collect although most of the households didn't separate the recyclable materials.

In the Paranapanema 4, the majority declares that cleaning is biweekly and most of the respondents in Terra Rica (9) have argued that cleaning occurs weekly.

The situation is most critical in Pirapó because all respondents reported the lack of public cleaning, with the exceptions of Arapongas ( 1 family) and Colorado (1 family). In all municipalities there is no collect of construction debris and rubble or debris from trees. In these municipalities, when comparing the Tables 11 and 12, we see a curious situation because, while most claims separate waste also claims that there is no garbage collection by the public sector, with the exception of one family in Arapongas and another one in Colorado. This situation deserves further clarification.

These situations which were described point to the problems generated by waste of the establishments, which may be impacting the environment, including rivers.

Another aspect that was investigated was the view of environmental problems and, again, the basins have different characteristics. Among the various problems studied, treated the native vegetation. In the Pirapó river basin, the area of native vegetation coverage increased in percentage (49.1\%) in the period 2008-2011. In the same period, the Paranapanema 3 reduced its coverage area by $3.3 \%$ and Paranapanema 4 declined sharply its area of native vegetation coverage $(43.0 \%)$, according IPARDES (2013)

As a result of field research, the view of the respondents with regard to rainfall, the floods, erosion, pollution of rivers, among others, i.e., the outlined imbalances are presented in Table 13.

There was no record of flooding and water logging in rural households of respondents as well as water rationing, with the exception of one family in Paranacity (Pirapó) and another one in Terra Rica (Paranapanema 4).

We chose to present the data by frequency and percentage clarifying that there are environmental issues that were systematized in an aggregate form such as soil erosion and compaction and clearing of the banks of rivers and siltation of rivers, in the Table 13. Thus, the first observation to be made with respect to the data collected in rural households is the low percentage of responses, including the Maringá's respondent that do not answered these questions, although he had answered the others. There are some explanations for this: (a) they were unable to have the dimension of the problem; (b) they do not want to answer; (c) they do not want to point out the problem by not having the notion of the consequences of their answer; (d) they do not know how to respond. This is an aspect to be better researched, although it is believed to be the alternative a that best explains this situation.

With respect to soil erosion and soil compaction in all municipalities surveyed there was the record of the respondents, with the exception of Arapongas. Deforestation and siltation of rivers is also registered with the exception 
Table 13. Frequency and percentage of environmental problems raised by rural families -2013 .

\begin{tabular}{|c|c|c|c|c|c|c|c|c|}
\hline \multirow[t]{2}{*}{ Municipalities } & \multicolumn{2}{|c|}{$\begin{array}{l}\text { Soil erosion and } \\
\text { soil compaction }\end{array}$} & \multicolumn{2}{|c|}{$\begin{array}{l}\text { Deforestation and } \\
\text { siltation of rivers }\end{array}$} & \multicolumn{2}{|c|}{$\begin{array}{c}\text { Urban and hospital } \\
\text { waste }\end{array}$} & \multicolumn{2}{|c|}{ Polluted rivers } \\
\hline & $\mathbf{Q}$ & $\%$ & $\mathbf{Q}$ & $\%$ & $\mathbf{Q}$ & $\%$ & $\mathbf{Q}$ & $\%$ \\
\hline \multicolumn{9}{|l|}{ Paranapanema 3} \\
\hline B.Vista Paraíso (6) & 3 & 50 & 1 & 16.7 & 1 & 16.7 & 1 & 16.7 \\
\hline Cambé (5) & 1 & 20 & - & & 2 & 40 & 1 & 20 \\
\hline Miraselva (18) & 2 & 11.1 & 4 & 22.2 & 2 & 22.2 & & \\
\hline Sub total (29) & 6 & 20.7 & 4 & 13.8 & 5 & 17.2 & 2 & 6.9 \\
\hline \multicolumn{9}{|l|}{ Paranapanema 4} \\
\hline Alto Paraná (13) & 2 & 15.4 & 5 & 38.5 & 1 & 7.7 & 2 & 15.4 \\
\hline Paranavaí (4) & 1 & 25.0 & 2 & 50.0 & - & & 1 & 25.0 \\
\hline Terra Rica (15) & 3 & 2.0 & 4 & 26.7 & 1 & 6.7 & - & \\
\hline Subtotal (32) & 6 & 18.8 & 11 & 34.4 & 2 & 6.3 & 3 & 9.4 \\
\hline \multicolumn{9}{|l|}{ Pirapó } \\
\hline Arapongas (2) & - & - & 2 & 100.0 & - & - & 1 & 50 \\
\hline Colorado (6) & 3 & 50.0 & 3 & 50.0 & 3 & 50.0 & 5 & 83.3 \\
\hline Maringá (1) & - & - & - & - & - & - & - & - \\
\hline Paranacity (8) & 2 & 25.0 & 4 & 50.0 & 1 & 37.5 & 3 & 37.5 \\
\hline Sub total (17) & 5 & 29.4 & 9 & 52.9 & 4 & 23.5 & 9 & 52.9 \\
\hline
\end{tabular}

Source: Field research (2013).

Table 14. Use of Rivers by the rural families -2013 .

\begin{tabular}{|c|c|c|c|c|c|c|}
\hline Municipalities & Don't use & recreation & irrigation & Consumption & Fishery & Others \\
\hline \multicolumn{7}{|l|}{ Paranapanema 3} \\
\hline B.Vista Paraíso (6) & 4 & 1 & & & 1 & \\
\hline Cambé (5) & 3 & & 2 & & & \\
\hline Miraselva (18) & 16 & 1 & 1 & & & \\
\hline Sub total (29) & 23 & 2 & 3 & $\mathbf{0}$ & 1 & $\mathbf{0}$ \\
\hline \multicolumn{7}{|l|}{ Paranapanema 4} \\
\hline Alto Paraná (13) & 7 & 2 & & & 4 & \\
\hline Paranavaí (4) & 4 & & & & & \\
\hline Terra Rica (15) & 9 & 4 & & & 2 & \\
\hline Sub total (32) & 20 & 6 & $\mathbf{0}$ & $\mathbf{0}$ & 6 & $\mathbf{0}$ \\
\hline \multicolumn{7}{|l|}{ Pirapó } \\
\hline Arapongas (2) & & 2 & 2 & & & \\
\hline Colorado (6) & 3 & 3 & & & & \\
\hline Maringa (1) & 1 & & & & & \\
\hline Paranacity (8) & 7 & & & & 3 & \\
\hline Sub total (17) & 11 & 5 & 2 & $\mathbf{0}$ & 3 & $\mathbf{0}$ \\
\hline TOTAL (78) & 54 & 13 & 5 & $\mathbf{0}$ & 10 & $\mathbf{0}$ \\
\hline
\end{tabular}

Source: Field research (2013).

of Cambé. Improper disposal of urban and hospital waste is also noted, with the exception of Paranavaí and Arapongas.

Furthermore, among those who answered the question occurred higher frequency on the polluted rivers. However, while respondents from the three basins pointing the problem, often did not know or did not indicate the source as the pesticides. As always, environmental issues always create resistance in the responses.

Regarding the use of rivers, we present the Table 14.
According to the data presented in the table, with the exception of Maringa and Paranavai, in which respondents use the rivers for any activity, it is observed that the vast majority of rural households do not use the rivers (69.2\%). Those who use, do for recreation and fishing (29.5\%) and irrigation (6.4\%) located predominantly in Paranapanema 3 (3 families) and Pirapó (2 families). This low frequency in the use of rivers for recreation and / or productive activity is interesting because, in part, may explain some distance from the developed practices and environmental impacts. 


\section{Conclusions}

The region has no problems in terms of water quantity, because the availability is always greater than the demand, although access to this water in some municipalities demands investments in expansion the distribution system (public investment, therefore). Since there are no quantitative problems, the issues listed assume qualitative nature. The rivers and their tributaries receive originating from domestic, industrial and rural discharges pollutant loads, although there is increasing actions for their treatment, particularly in Pirapó. In this basin, there are high percentages of wastewater that in rural areas, which do not receive any treatment. In the urban sector, the percentage of treatment tend to increase.

The socioeconomic conditions of the interviewed families in the selected municipalities are differentiated, and the 'best condition' is in the Pirapó River Basin due to its history marked by a hub city (Maringá), since the colonization and severe process of implementing the green revolution. The conclusion is that there are a number of factors (economic activities, total population, GDP and GDP per capita) that reinforce or were reinforced by soil type and therefore interfere with the demand of water resources.

What can be concluded with data collected is that many environmental problems or are not perceived and / or does not make the relationship between the practices and impacts, particularly on water resources. We can mention the issue of waste, while only 11 households / respondents stated that there are problems in the disposal of waste (Table 13), at the same time 31 families stated that they do not sort rubbish (Table 10). Another example is that although 24 families indicate the problem of deforestation and silting of rivers, only 9 families (Table 10) makes the recovery of riparian forests. Pollution of rivers was noted, particularly in the river basin Paranapanema 3 for two families (Table 13) while 10 families had no septic tank, 20 of the 29 families have pig farming and only 11 have pigsties.

During the interviews, there was much resistance to answer questions relating to the environment and its impacts.

\section{References}

AGÊNCIA NACIONAL DE ÁGUAS - ANA, 2012 [viewed 1 June 2012]. Atlas Brasil: abastecimento urbano de água [online]. Brasília. Available from: http://atlas.ana.gov.br/atlas/ forms/analise/Geral.aspx ?mun $=4119 \&$ mapa $=$ sist

BRASIL, 1981 [viewed 1 March 2014]. Lei $n^{\circ}$ 6938, de 31 de outubro de 1981. Dispõe sobre a Politica Nacional de Meio Ambiente, seus fins e mecanismos de formulação e aplicação, $e$ dá outras providências. Diário Oficial da República Federativa do Brasil [online], Brasília, 2 set. Available from: http://www. mma.gov.br/port/conama/legiabre.cfm? codlegi $=313$

BRASIL, 1988 [viewed 1 March 2014]. Constituição da República Federativa do Brasil de 1988. Diário Oficial da República Federativa do Brasil [online], Brasília, 5 out. Available from: http://www.planalto.gov.br/ccivil_03/constituicao/ ConstituicaoCompilado.htm
BRASIL, 1997 [viewed 1 March 2014]. Lei $n^{\circ}$ 9.433, de 8 de janeiro de 1997. Institui a Política Nacional de Recursos Hidricos, cria o Sistema Nacional de Gerenciamento de Recursos Hídricos, regulamenta o inciso XIX do art. 21 Da Constituição Federal e altera o art. 1 da Lei n0. 8.001 de 13 de março de 1990, que modificou a Lei n. 7.990 de 28 de dezembro de 1989. Diário Oficial da União [online], Brasília, 9 jan. Available from: http:// www.planalto.gov.br/ccivil_03/leis/L9433.HTM

BRASIL, 2000 [viewed 1 March 2014]. Lei no 9984, de 17 de julho de 2000. Dispõe sobre a Criação da Agência Nacional de Águas - ANA, entidade federal de implementaçãoda Politica Nacional de Recursos Hidricos e de coordenação do Sistema Nacional de Gerenciamento de Recursos Hídricos, e dá outras providências. Diário Oficial da União [online], Brasília, 18 jul. Available from: http://www.planalto.gov.br/ccivil_03/LEIS/ L9984.htm

BRASIL. Ministério do Desenvolvimento Social e Combate à Fome - MDS, 2013a [viewed 1 October 2013]. Relatório de informações sociais [online]. Brasília. Available from: http:// aplicacoes.mds.gov.br/sagi/RIv3/geral/index.php

BRASIL. Ministério do Meio Ambiente, dos Recursos Hídricos e da Amazônia Legal - MMA, 2013b [viewed 1 March 2014]. Alimentos: os impactos na produção [online]. Brasília. Available from: http://www.mma.gov.br/estruturas/secex_consumo/_ arquivos $/ 4 \% 20-\% 20 \mathrm{mcs}$ alimentos.pdf

GODOY, A.M.G. and SOUSA, M.L.L., 2012. Avaliação do uso e ocupação do solo nas bacias hidrográficas do Pirapó, Paranapanema III e IV. Periódico Eletrônico Fórum Ambiental da Alta Paulista, vol. 8, no. 2, pp. 160-180. Anais do VIII Fórum Ambiental da Alta Paulista.

INSTITUTO BRASILEIRO DE GEOGRAFIA E ESTATÍSTICA - IBGE, 2012 [viewed 1 June 2012]. IBGE Cidades [online]. Brasília. Available from: http://www.ibge.gov.br/cidadesat/ topwindow.htm?1

INSTITUTO PARANAENSE DE DESENVOLVIMENTO ECONÔMICO E SOCIAL - IPARDES, 2012 [viewed 1 June 2012]. Cadernos municipais [online]. Curitiba. Available from: http://www.ipardes.pr.gov.br/index.php?pg_conteudo=1\&cod_ conteudo $=30$

INSTITUTO PARANAENSE DE DESENVOLVIMENTO ECONÔMICO E SOCIAL - IPARDES, 2013 [viewed 1 June 2013]. Síntese dos indicadores ambientais por bacias hidrográficas do Paraná [online]. Curitiba. Available from: http://www.ipardes. gov.br/pdf/mapas/base_ambiental/indicadores_ambientais.pdf

PARANÁ, 1999 [viewed 1 June 2013]. Lei $n^{\circ}$ 12.726, de 26 de novembro de 1999. Institui a Política Estadual de Recursos Hidricos e adota outras providências. Diário Oficial do Estado [online], Curitiba, 29 nov. Available from: http://www.legislacao. pr.gov.br/legislacao/pesquisarAto.do?action $=$ exibir\&codAto $=5$ $849 \&$ indice $=1 \&$ totalRegistros $=1$

PARANÁ. Secretaria de Estado do Meio Ambiente e Recursos - SEMA, 2006 [viewed 1 February 2014]. Resolução 024 de 06 de junho de 2006. Institui as diretrizes para a gestão de Bacias Hidrográficas. Available from: http://celepar7.pr.gov.br/sia/ atosnormativos/form_cons_ato1.asp?Codigo $=1355$

PARANÁ. SUDERHSA, 2007 [viewed 1 June 2012]. Bacias hidrográficas do Paraná [online]. Curitiba. Available from: http://www.aguasparana.pr.gov.br/arquivos/File/DADOS\%20 ESPACIAIS/Bacias_Hidrograficas_A4.pdf 
PARANÁ. Agência Nacional de Águas - ANA. Secretaria de Estado do Meio Ambiente e Recursos - SEMA, 2010 [viewed June 2013]. Bacias hidrográficas do Paraná [online]. Curitiba. Available from: http://www.meioambiente.pr.gov.br/arquivos/ File/corh/Revista_Bacias_Hidrograficas_do_Parana.pdf

PARANÁ. Instituto das Águas - IA, 2012a [viewed 1 June 2012]. Recursos hídricos no Estado do Paraná. Curitiba. Available from: http://www.aguasparana.pr.gov.br/arquivos/File/BACIAS/pirapo.pdf
PARANÁ. Secretaria do Planejamento e Coordenação Geral - SEPL. Secretaria da Agricultura e Abastecimento - SEAB. Secretaria da Educação - SEED. Secretaria da Saúde - SESA, 2012b [viewed March 2014]. Marco gestão ambiental: projeto multissetorial para o desenvolvimento do Paraná [online]. Curitiba. Available from: http://www.sepl.pr.gov.br/arquivos/ File/Arquivos\%20PDF\%20/PGA_II_2012_1.pdf 